\title{
Pyloric Sphincter
}

National Cancer Institute

\section{Source}

National Cancer Institute. Pyloric Sphincter. NCI Thesaurus. Code C33433.

The muscular structure at the distal portion of the stomach, opening into the duodenum. 